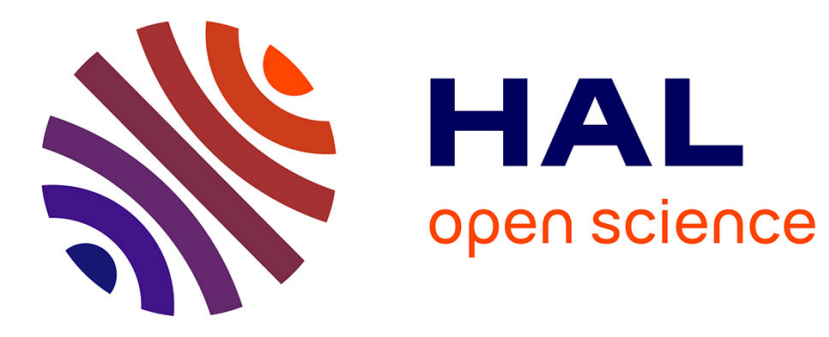

\title{
Single crystal fiber for laser sources (Orale)
}

Xavier Délen, Adrien Aubourg, Loïc Deyra, Fabien Lesparre, Igor Martial, Julien Didierjean, François Balembois, Patrick Georges

\section{To cite this version:}

Xavier Délen, Adrien Aubourg, Loïc Deyra, Fabien Lesparre, Igor Martial, et al.. Single crystal fiber for laser sources (Orale). Photonics West 2015, Solid State Lasers XXIV: Technology and Devices, Feb 2015, San Francisco, United States. pp.934202, 10.1117/12.2081184 hal-01137732

\section{HAL Id: hal-01137732 https://hal.science/hal-01137732}

Submitted on 31 Mar 2015

HAL is a multi-disciplinary open access archive for the deposit and dissemination of scientific research documents, whether they are published or not. The documents may come from teaching and research institutions in France or abroad, or from public or private research centers.
L'archive ouverte pluridisciplinaire HAL, est destinée au dépôt et à la diffusion de documents scientifiques de niveau recherche, publiés ou non, émanant des établissements d'enseignement et de recherche français ou étrangers, des laboratoires publics ou privés. 


\title{
Single crystal fiber for laser sources \\ XavierDélen ${ }^{1}$, Adrien Aubourg ${ }^{1,2}$, Loïc Deyra ${ }^{1}$, Fabien Lesparre ${ }^{1,2}$, Igor Martial ${ }^{2}$, Julien Didierjean $^{2}$,François Balembois ${ }^{1}$, Patrick Georges ${ }^{1}$ \\ ${ }^{1}$ Laboratoire Charles Fabry, UMR 8501, Institut d'Optique, CNRS, Univ Paris Sud, 2 Avenue A. Fresnel, 91127 Palaiseau Cedex, France ${ }^{2}$ Fibercryst SAS, Parc d'activité Wilson Bât A1, 31 Rue Wilson, F-69150 DecinesCharpieu, France \\ ${ }^{*}$ Corresponding author: patrick.georges@institutoptique.fr
}

\section{Summary (100 mots):}

Single crystal fiber (SCF) is a hybrid laser architecture between conventional bulk laser crystals and active optical fibers allowing higher average powers than conventional crystals and higher energy than in fibers in pulsed regime. The pump beam is confined by the guiding capacity of the SCF whereas the signal beam is in free propagation. In this paper, we present an overview of the results obtained with SCF Er:YAG oscillators emitting at $1617 \mathrm{~nm}$, SCF Nd:YAG oscillators emitting at $946 \mathrm{~nm}$, a high power Yb:YAG SCF oscillator and pulse amplification experiments achieved with diode-pumped Nd:YAG SCF and Yb:YAG SCF.

\begin{abstract}
(250 mots)
Single crystal fiber (SCF) is a hybrid laser architecture between conventional bulk laser crystals and active optical fibers allowing higher average powers than with conventional crystals and higher energy than with fibers in pulsed regime. The pump beam delivered by a fiber-coupled laser diode is confined by the guiding capacity of the SCF whereas the signal beam is in free propagation. In this paper, we study the pump guiding in the SCF and give an overview of the results obtained using SCF gain modules in laser oscillators and amplifiers. We report about up to $500 \mu \mathrm{J}$ nanosecond pulses at the output of a passively Q-switchedEr:YAG SCF oscillator at $1617 \mathrm{~nm}$. High power experiments with Yb:YAG allowed to demonstrate up to $250 \mathrm{~W}$ out of a multimode oscillator. High power $946 \mathrm{~nm} \mathrm{Nd:YAG} \mathrm{SCF} \mathrm{oscillators} \mathrm{followed} \mathrm{by} \mathrm{second} \mathrm{and} \mathrm{fourth} \mathrm{harmonic}$ generation in the blue and the UV is also presented with up to $3.4 \mathrm{~W}$ at $473 \mathrm{~nm}$ and $600 \mathrm{~mW}$ at $236.5 \mathrm{~nm}$. At $1064 \mathrm{~nm}$, we obtain up to $3 \mathrm{~mJ}$ with a nearly fundamental mode beam in sub-nanosecond regime with a microchip laser amplified in a Nd:YAG SCF. Yb:YAG SCF amplifiers are used to amplify fiber based sources limited by non-linearities with a narrow linewidth laser and with a femtosecond source. Using chirped pulse amplification, $380 \mathrm{fs}$ pulses are obtained with an energy of $1 \mathrm{~mJ}$ and an excellent beam quality $\left(\mathrm{M}^{2}<1.1\right)$.
\end{abstract}

